\title{
NAREDBA UPRAVNIKA GRADA BEOGRADA O USPOSTAVLJANJU SLUŽBE OBEZBEĐENJA PREDSEDNIKA VLADE MILANA NEDIĆA
}

Rimska Pretorijanska garda, Gvardija kneza Miloša, američka Tajna služba, samo su deo specijalizovanih službi koje su kroz istoriju imale zadatak da štite važne državne funkcionere od unutrašnjeg i spoljnog neprijatelja. Moderna policijska doktrina, termin obezbeđenje determiniše kao „organizovanu i plansku primenu mera, radnji i sredstava u cilju zaštite od ugrožavanja određenih ličnosti, lica, objekata, prostora i skupova. " ${ }^{1}$ Vrsta i obim obezbeđenja koje će lice dobiti u zavisnosti je od važnosti funkcije koju obavlja, ali i bezbedonosnih procena.

Pokušaćemo da za trenutak uđemo u ulogu policijskog analitičara u nameri da rekonstruišemo stanje bezbednosti u kojem se našla Vlada Milana Nedića. ${ }^{2}$ Od 22. juna 1941. na teritoriji okupirane Srbije gori antifašistički ustanak organizovan i vođen od strane dva pokreta otpora. Paljenje zgrada i opštinskih arhiva, oružani napadi i ubistva kolaboracionističkih zvaničnika bili su učestala pojava. U Beogradu, koji je bio centar okupacione i kolaboracionističke uprave, komunistički ilegalci izvodili su najrazličitije oružane akcije. Do smirivanja situacije došlo je tek po angažovanju dodatnih nemačkih trupa i obrazovanju Vlade Milana Nedića. ${ }^{3}$ Bez obzira

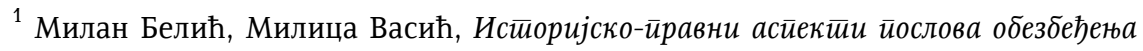

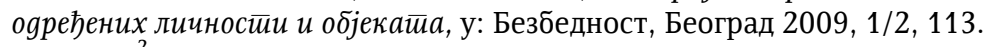

${ }_{2}$ Milan Đ. Nedić, armijski general (1877-1946). Posle završene niže i više vojne škole bio na službi u Kraljevoj gardi, kao ordonans kralja Petra, načelnik Đeneralštaba vardarske divizijske oblasti itd. Učesnik u Balkanskim ratovima i Prvom svetskom ratu. Vrhunac u svojoj predratnoj karijeri dostigao je u periodu od 1934. i do 1940, kada je najpre obavljao dužnost načelnika Glavnog generalštaba, a zatim ministra vojske i mornarice. U Aprilskom ratu bio je komandant 3. grupe armija. Pod okupacijom, od avgusta 1941. do 1944, bio je predsednik kolaboracionističke vlade u okupiranoj Srbiji. Od strane američkih organa izručen je komunističkim vlastima u Jugoslaviji, gde je prema zvaničnoj verziji izvršio samoubistvo u toku istrage: Mile Bjelajac, Generali i admirali Kraljevine Jugoslavije 1918-1944. Studija o vojnoj eliti i biografski leksikon, Beograd 2004, 224-225.

${ }^{3}$ Više o ovoj temi u: Branko Petranović, Srbija u Drugom svetskom ratu 1939-1945,

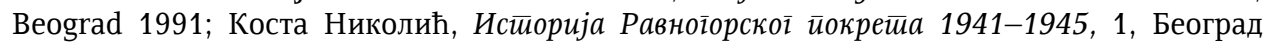


na ovu činjenicu, visoki zvaničnici kolaboracionističke uprave nisu se našli u bezbednijem okruženju. Komunistički pokret otpora je od septembra iste godine u Beogradu projektovao nov način borbe čija je suština bila da se putem atentata na kolaboracionističke organe destabilizuje ovaj režim. ${ }^{4} \mathrm{Ni}$ pripadnici Jugoslovenske vojske $u$ otadžbini nisu blagonaklono gledali na delatnost Vlade Milana Nedića. U leto 1942, na zahtev ravnogoraca, preko Radio Londona objavljen je spisak imena ministara pod nazivom „potomci Vuka Brankovića“, čija su imena stavljena pod slovo „Z“. ${ }^{5}$ Pored komunističkog i ravnogorskog pokreta otpora, koji su predstavljali glavnu bezbednosnu pretnju, potrebno je ukazati i na činjenicu da ni većina običnih građana nije podržavala rad ove vlade i da je iz njihovog ugla to bila otvorena izdaja. Ovakvo stanje stvorilo je potrebu da od prve godine okupacije policija posebnu pažnju posveti zaštiti. Uprava grada Beograda (UGB) bio je organ koji je i u predratnom periodu imao u svom delokrugu rada zaštitu lica i objekata. Upravnik grada je već 6. jula 1941. naredio da se preduzmu „mere za obezbeđenje zgrada i prostorija“ u kojima su bila smeštena kolaboracionistička nadleštva, te da se za ove potrebe izdvoji potreban broj agenata i stražara. ${ }^{6}$ O sistematičnosti kojom je Uprava grada Beograda prilazila ovom problemu svedoči Naredba br. 25 od 2. novembra 1941, koja se sastojala od niza zaštitnih mera u nameri da se spreče akta atentata i sabotaže. ${ }^{7}$ Osim službenika UGB o ličnoj bezbednosti Milana Nedića starala se i Srpska garda. Kako navodi istoričar Bojan B. Dimitrijević bila je to "brojčano mala formacija, osnovana od najboljih pripadnika" Srpske državne straže čiji zadatak je bio da vrše stražarsku, ceremonijalnu i počasnu dužnost pred Predsedništvom vlade. ${ }^{8}$ Naredba koju objavljujemo nastala je kao plod težnji policijskih organa da se, radi što efikasnije zaštite Milana Nedića i zgrade Predsedništva vlade, objedine i preciziraju dužnosti svih činilaca koji su bili uposleni na ovom zadatku. Dokument, prema našim saznanjima, nije do sada objavljivan i nalazi se pohranjen u Istorijskom arhivu Beograda $u$ fondu Uprave grada Beograda. ${ }^{9}$

1999; Jovan Marjanović, Ustanak i Narodnooslobodilački pokret u Srbiji 1941, Beograd 1963; Бојан Б. Димитријевић, Војска Неgићеве Србије. Оружане снаіе срйске влаgе 1941-1945, Београд 2011.

${ }^{4}$ Раде Ристановић, Акције комунисйичких илеїлаи, у Беоїраgу 1941-1942, Београд 2013, 179-186.

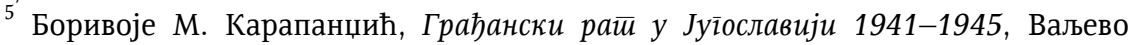
2010, 221-251.

${ }^{6}$ Istorijski arhiv Beograda (dalje: IAB), Uprava grada Beograda (dalje: UGB), Odeljenje specijalne policije (dalje: SP), IV-116.

${ }^{7}$ Vojni arhiv (dalje: VA), Nedićeva arhiva (dalje: Nda), k. 57, f-1, d-5.

${ }^{8}$ Б. Б. Димитријевић, н. g., 263.

${ }^{9} \mathrm{IAB}, \mathrm{UGB}, \mathrm{SP}, \mathrm{IV}-162$. 
UPRAVA GRADA BEOGRADA

ODELJENJE SPECIJALNE POLICIJE

Pov. Br. 3150

27 novembra 1943 godine

Beograd

Da bi bezbednost Pretsednika vlade bila potpuno zagarantovana i da bi zgrada u kojoj je smešteno Predsedništvo i Ministarstvo unutrašnjih poslova bila potpuno obezbeđena, to u smislu ovlašćenja Pretsedništva Ministarskog saveta D.S.br.143, od 22 novembra t.g.

\section{NAREĐUJEM}

\section{I}

\section{ORGANI}

Šef službe bezbednosti.

Za šefa službe bezbednosti Pretsednika vlade određujem policijskog komesara TRIPKOVIĆ ĐURU. ${ }^{10}$

Organi.

Šefu službe bezbednosti dodeljuje se potreban broj gardista i 10 policijskih agenata, koje će šef službe rasporediti na obezbeđenju zgrade Pretsedništva vlade i za lično obezbeđenje Pretsednika, prilikom njegovog kretanja po gradu i van grada.

II

\section{RASPORED ORGANA}

a) Gardisti.

1. - Jedno stražarsko mesto na glavnom ulazu iz Kralja Milana ulice.

2. - Jedno stražarsko mesto na ulazu iz Dobrinjske ulice.

3. - Jedno stražarsko mesto na terasi garaže u zgradi Pretsedništva. vlade.

4. - Jedno stražarsko mesto pred vratima prostorija Predsednika

${ }^{10}$ Đuro Tripković je rođen 29. marta 1904. u Užicu. Po okončanju gimnazije upisao je Pravni fakultet u Beogradu i do 1941. završio tri godine studija. U Upravi grada Beograda zaposlio se u maju 1931, a poslednji poznati položaj bio mu je policijski komesar. Po okupaciji do imenovanja na dužnost šefa službe bezbednosti predsednika vlade radio je kao referent u jednom od odseka Odeljenja specijalne policije; VA, Nda, K. 133, f. 2, d. 7/9. 
5. - Komandir gardiske straže ili razvodnik imaju se stalno nalaziti u holu glavnog ulaza.

\section{b) Policijski agenti.}

1. - 4 policijska agenta na glavnom ulazu iz Kralja Milana ulice. Služba traje od 7.30 do 20.30 časova. U koliko pretsednik do ovog vremena ne izađe iz zgrade, služba se produžava do njegovog izlaska.

2. -3 policijska agenta na ulazu iz Dobrinjske ulice. Služba traje od 6 do 21 čas.

3. - 3 policijska agenta za ličnu pratnju pretsednika prilikom njegovog kretanja po gradu i van grada.

v) Policijski stražari.

Jedno stalno pozornično mesto u neposrednoj blizini zgrade Pretsedništva vlade u ulici Kralja Milana i Dobrinjskoj.

\section{III}

\section{POJAČANA SLUŽBA}

U slučaju potrebe, da se bezbednost pojača, kao i za vreme stroge pripravnosti pojačava se stražarska služba na ulazima i na terasi nad garažom sa po još jednim stražarom-gardistom. Pred zgradom Pretsedništva u mesto pozornika, obrazuje se jedna, a prema potrebi i više policijskih patrola.

\section{IV}

\section{DUŽNOST ORGANA NA OBEZBEĐENJU}

Šef službe bezbednosti vršiće raspored službe civilnih organa i kontrolu nad celokupnim osobljem na obezbeđenju i izdavati potrebna naređenja i instrukcije za službu. Prilikom svakog izlaska Pretsednika pratiće ga, u koliko se drugačije ne naredi. U slučaju privremene otsutnosti šefa bezbednosti, zameniće ga organ koga on bude odredio a u slučaju duže odsutnosti odrediće mu se zamenik po predlogu šefa Odeljenja specijalne policije.

Garda je u službenom pogledu potčinjena šefu bezbednosti, a u pogledu discipline, stručne nastave, naoružanja, reda i rasporeda službe komandiru straže Srpske garde.

Stražarski gardisti na ulazima iz Kralja Milana i Dobrinjske ulice imaju za dužnost, da motre na sva lica, koja ulaze u zgradu i da u slučaju 
potrebe ukazuju pomoć civilnim organima, koji vrše službu u holovima kod ulaza. Naročitu pažnju imaju obratiti na bezbednost Pretsednika vlade prilikom njegovog ulaska i izlaska iz zgrade.

Stražar gardista na terasi garaže ima da motri, da se neko iz susednih dvorišta ne prebaci u dvorište ili zgradu Pretsedništva. Svakome bez razlike ima da zabrani prolaz u zgradu Pretsedništva van određenog ulaza.

Stražari gardisti pred ulazima i terasi vrše službu sa velikim oružjem.

Stražar gardista pred vratima prostorije predsednika vlade vršiće obezbeđenje Predsednika vlade za vreme dok se Pretsednik nalazi u kancelariji, a u otsustvu Predsednika obezbeđivaće prostorije kabineta.

Komandir straže i razvodnik koji se za celo vreme nalazi u holu glavnog ulaza ukazivaće, prema potrebi, pomoć civilnim organima, koji na tom mestu vrše službu.

Gardisti koji su u holu i pred vratima Pretsednika vlade vrše službu sa malim oružjem - revolverom.

Ključevi od ulaza nalaziće se kod komandira gardiske straže, koji će ulaz iz Kralja Milana ulice otključavati u 7.30 a zaključavati u 20.30 časova. Ako Pretsednik do toga vremena nije izišao iz zgrade, ulaz će zaključati po njegovom izlazku. Ulaz iz Dobrinjske ulice otključavaće u 6 časova, a zaključavaće u 21 čas.

Civilni organi na glavnom ulazu iz Kralja Milana ulice imaju za dužnost, da vrše kontrolu nad svim licima, koja ulaze i izlaze iz zgrade. Sva nepoznata lica legitimisaće i pregledati im prtljag, a u slučaju potrebe izvršiti im i lični pretres. Na ovaj ulaz puštaće samo ona lica, kojima je odobreno naredbom Državnog sekretara pri Pretsedništvu vlade i za koja se iz kabineta Pretsedništva, naredi da se pusti. Sva ostala lica upućivati na ulaz iz Dobrinjske ulice. Prilikom dolaska i izlaska Pretsednika vlade iz zgrade ovi organi da obezbeđuju slobodan i bezopasan prolaz Pretsednika.

Civilni organi na ulazu iz Dobrinjske ulice vrše legitimisanje i pretres prtljaga, a u slučaju potrebe i lične pretrese lica koja ulaze u zgradu, u cilju pronalaska oružja, eksploziva i slično. Prtljag koji lica nose sa sobom, zadržavaju i vraćaju sopstvenicima prilikom njihovog izlaska iz zgrade.

Policijski stražar-pozornik, koji vrši službu na ulici pred zgradom Predsedništva ima za dužnost da spreči svako nepotrebno zadržavanje građanstva pred Pretsedništvom, a naročito pred ulazom, da obraća pažnju na lica koja se kreću i zadržavaju na drugoj strani trotoara. Kada pretsednik dolazi ili izlazi iz pretsedništva pozornik se ima nalaziti na suprotnom trotoaru ili na mestu odakle opasnost po bezbednosti Pretsednika najpre i najviše može da nastupi. 
Stražari-gradisti i policijski agenti na ulazima, stražar-gardista na terasi, kao i policijski stražar-pozornik imaju za dužnost da kontrolišu da neko od prolaznika ne ostavi kakav predmet pred zgradom ili u blizini zgrade Pretsedništva, ili da neko ne ubaci kroz prozor kakav predmet čime bi se ugrozila bezbednost zgrade i ličnosti u zgradi.

Organi angažovani ovom naredbom za bezbednost imaju svoje dodeljene ima dužnosti obavljati najpažljivije i najsavesnije, sa puno volje, takta, obazrivosti i požrtvovanosti.

U koliko se ukaže potreba za izmenom službe bezbednosti predviđene ovom naredbom, Šef službe bezbednosti učiniće mi obrazloženi predlog.

O izvršenju ove naredbe staraće se šef službe bezbednosti policiski komesar Tripković Đura.

O stalnoj kontroli službe šef Specijalne policije ili njegov pomoćnik.

UPRAVNIK GRADA BEOGRADA JOVANOVIĆ 